Шкромада О. І., кандидат ветеринарних наук

Сумський національний аграрний університет

\title{
ОЦНКА БАКТЕРИЦИДНИХ ВЛАСТИВОСТЕЙ КОМПЛЕКСНОГО МЕТАЛОМІСТКОГО ДЕЗІНФЕКТАНТУ
}

\section{Рецензент - доктор ветеринарных наук М. І. Харенко}

\begin{abstract}
Наведені дані за результатами досліджень бактерицидної дії комплексного металомісткого дезінфектанту. Для изього визначали фенольний коефічієнт, який виражає відношення концентрачії розчинів досліджуваної речовини до концентрації фенолу, щзо спричиняють у рівний проміжок часу за однакової температури рівнозначний температурний дезінфікуючий ефект. Також визначали білковий індекс, показник зниження активності дезінфікуючого засобу в присутності білків. У результаті досліджень встановлено, щзо бактерицидна дія комплексного металомісткого дезінфектанту (КМД) сильніша за бактерищидну дію карболової кислоти в 157,98 разу. КМД може проявляти бактерицидну дію на оброблюваних поверхнях навіть за контакту з білковими субстанціями, хоча в такому випадку його ефективність знизиться в 2,92 разу, щуо враховано при встановленні ефективних концентрацій робочих розчинів КМД.
\end{abstract}

Ключові слова: фенольний коефіиієнт, бактерицидна дія, білковий індекс, комплексний металомісткий дезінфектант.

Постановка проблеми. 3 кожним роком кількість сільськогосподарських тварин через потребу населення у харчуванні в усьому світі зростає. Тому необхідно чітко дотримуватися правил 3 утримання тварин на фермах i комплексах. Витримування санітарних і гігієнічних вимог може зменшити ризик розповсюдження захворювань між людиною і твариною через стічні води, гній, грунт, повітря тощо. 3 цією метою для профілактики необхідно використовувати дезінфекцію у господарствах, спеціалізованих із вирощування тварин.

Аналіз основних досліджень і публікацій, у яких започатковано розв'язання проблеми Перспективним напрямом створення нових й удосконалення наявних дезінфекційних засобів $\epsilon$ розробка багатокомпонентних препаратів, до складу яких входить декілька компонентів із різних класів хімічних сполук, що взаємодоповнюють одна одну щодо спектру протимікробної активності та спроможності запобігати поширенню стійких до них мікроорганізмів. Експериментальною основою розробки багатокомпонентних засобів дезінфекції є результати досліджень взаємодії препаратів різної хімічної будови між собою та з активуючими добавками, мийними, диспергуючими сполуками, інгібіторами корозії, наповнювачами тощо [2].

Метою створення таких препаратів є розширення спектру протимікробної активності й здатності запобігати виникненню резистентних мікроорганізмів. Окрім того, ці дезінфектанти повинні володіти також противірусною та фунгіцидною дією і бути екологічно безпечними.

Багатопрофільна обробка тваринницьких приміщень такими дезінфектантами сприятиме значному підвищенню ефективності використання запропонованого препарату відповідно до ветеринарно-санітарних вимог [1] .

Мета дослідження: визначення бактерицидного розведення та фенольного коефіцієнта композиції для обробки тваринницьких приміщень.

Матеріал і методи досліджень. Визначення бактерицидного розведення, визначення фенольного коефіцієнта, білкового індексу проводили згідно з чинними методиками $[3,4]$.

Для визначення бактерицидного розведення готували досліджуваний розчин. Початкова концентрація розчину 1:50 із прогресивним зменшенням діючої речовини в кожному наступному розведенні. Готували серію розчинів із кроком розведення 10.

Комплексний металомісткий дезінфектант (КМД) для обробки тваринницьких приміщень містить такі компоненти, мас. \%:

\begin{tabular}{|c|c|}
\hline Надоцтова кислота & $1,5-2$ \\
\hline $\begin{array}{c}\text { Жовтий залізоокисний пігмент } \\
\text { (ДСТУ ГОСТ 30333: 2009) }\end{array}$ & $1,8-2$ \\
\hline Сульфат міді & $0,18-0,2$ \\
\hline Вода & до 100 мас. \% \\
\hline
\end{tabular}

Одночасно готували бульйонну культуру E. coli тa S. aureus. Для приготування бульйонної культури у колбу наливали $25 \mathrm{~cm}^{3}$ бульйону i вносили у нього $0,25 \mathrm{~cm}^{3}$ добової бульйонної культури мікроорганізму. Через добу бульйонну культуру фільтрували через стерильний марле- 
во-ватний чи паперовий фільтр. У розставлені колби вносили по 0,5 cм cे $^{3} 4$-годинної бульйонної культури випробовуваних мікроорганізмів. Після десятихвилинного витримування із колб платиновою петлею брали проби і переносили у пробірки з бульйоном. Вказані види робіт проводили 3 дотриманням умов стерильності.

Через 30 хв, зберігаючи той же інтервал, знову брали проби і проводили вторинний посів на бульйон. Після цього колби з бульйоном ставили у термостат із температурою $37^{\circ} \mathrm{C}$. Перший раз посіви переглядали через 10 годин, а остаточно через 6-7 днів. Отримані результати наведені в таблиці 1.

\section{Бактерицидне розведення комплексного металомісткого дезінфектанту (КМД)}

\begin{tabular}{|c|c|c|}
\hline \multirow{2}{*}{$\begin{array}{c}\text { Розчини } \\
\text { дезінфектанту }\end{array}$} & Бактерицидне розведення КМД \\
\cline { 2 - 3 } & 10 & 30 \\
\hline Фенол $1: 50$ & $1: 98$ & $1: 192$ \\
\hline КМД $1: 50$ & $1: 16144,3$ & $1: 22125,2$. \\
\hline КМД + (білок) & $1: 5536,0$ & $1: 7585,2$ \\
\hline
\end{tabular}

Результати дослідження. Фенольний коефіцієнт виражає відношення концентрації розчинів досліджуваної речовини до концентрації фенолу, що спричиняють у рівний проміжок часу за однакової температури рівнозначний дезінфікуючий ефект.

Для досліджень брали хімічно чисту кристалічну карболову кислоту без домішок води.

Методика визначення фенольного коефіцієнту така ж, як і для визначення бактерицидного розведення.

Для одержання достовірних результатів дослід повторювали 5 разів і обчислювали значення середнього бактерицидного розведення фенолу та досліджуваного засобу окремо при 10- і 30хвилинній експозиції.

Середнє число бактерицидного розведення КМД ділили на середнє число бактерицидного розведення фенолу.

Отримана в результаті ділення цифра і $є$ фенольним коефіцієнтом комплексного металомісткого дезінфектанту, що показує, у скільки разів цей засіб діє сильніше чи слабше фенолу.

Розрахунок проводили так: бактерицидне розведення фенолу при 10-хвилинній експозиції дорівнює 1:9; при 30-хвилинній - 1:192.

Бактерицидне розведення КМД при 10хвилинній експозиції дорівнює 1: 16144,3; при 30-хвилинній - 1: 22125,2.

Звідси фенольний коефіцієнт для КМД при 10-хвилинній експозиції дорівнює:

фенольний коефіцієнт $=\frac{16144,3}{98}=164,73$;

при 30-хвилинній експозиції:

фенольний коефіцієнт $=\frac{22125,2}{192}=151,23$.

Середній фенольний коефіцієнт $=\frac{164,73+151,23}{2}=157,98$.

Отже, бактерицидна дія комплексного металомісткого дезінфектанту сильніша за бактерицидну дію карболової кислоти в 157,98 разу.

Визначення білкового індексу. У процесі практичного застосування дезінфекційний засіб зазвичай стикається не лише 3 мікроорганізмами, але й $з$ навколишнім середовищем, у якому можуть бути органічні й неорганічні речовини. Взаємодія $з$ ними призводить до зниження знезаражуючого ефекту.

У зв'язку з цим виникає необхідність визначити ступінь зниження активності досліджуваного засобу при взаємодії з зовнішнім середовищем. У якості останнього використовують білок у вигляді інактивованої сироватки.

Показник зниження активності дезінфекційного засобу в присутності високомолекулярного білка називається білковим індексом.

Для досліду готували ряд розведень розчину досліджуваного засобу КМД, які прогресивно знижуються, з коефіцієнтом 1:4.

Однак концентрація розчину повинна бути вдвічі вища, ніж за визначення фенольного коефіцієнту.

Дослідження проводили за діючою методикою [4].

Бактерицидне розведення комплексного металомісткого дезінфектанту за відсутності білку при 10-хвилинній експозиції дорівнює 1: 16144,3; при 30-хвилинній - 1: 22125,2.

Бактерицидне розведення в досліді з білком при:

10-хвилинній експозиції - 1: 5536,0;

30-хвилинній - 1: 7585,2.

Білковий індекс при:

10 -хвилинній експозиції $=\frac{16144,3}{5536,0}=2,91$,

30 -хвилинній експозиції $=\frac{22125,2}{7585,2}=2,92$.

Середній білковий індекс дорівнює $\frac{2,91+2,92}{2}=2,92$ 
Отже, бактерицидна дія комплексного металомісткого дезінфектанту в присутності білку знижується в 2,92 разу.

Отримані результати дають підстави зробити висновок, що комплексний металомісткий дезінфектант може проявляти бактерицидну дію на оброблюваних поверхнях навіть при контакті 3 білковими субстанціями, але в такому випадку його ефективність знизиться в 2,92 разу.

Цей фактор було враховано у процесі встановлення ефективних концентрацій робочих

\section{БІБЛІОГРАФІЯ}

1. Высоикий А. Э. Методы токсикологической оценки новых дезинфицирующих химиопрепаратов, применяемых в ветеринарии / А. Э. Высоцкий // Науково-технічний бюлетень Інституту біології тварин і ДНДКІ вет. препаратів та кормових добавок. - Львів, 2007. - Вип. 8. - № 3, 4. - C. 344-352.

2. Головенко М. Я. Наномедицина: досягнення та перспективи розвитку новітніх технологій у діагностиці та лікуванні / М. Я. Головенко // Журнал АМН розчинів КМД.

Висновки. Бактерицидна дія комплексного металомісткого дезінфектанту сильніша за бактерицидну дію карболової кислоти в 135,8 разу. Комплексний металомісткий дезінфектант може проявляти бактерицидну дію на оброблюваних поверхнях навіть при контакті з білковими субстанціями, але в такому випадку його ефективність знизиться в 2,83 разу. Цей фактор було враховано у процесі встановлення ефективних концентрацій робочих розчинів КМД.

України. - 2007. - Т. 13. - №4. - С. 4-25.

3. Поляков A. А. Основы ветеринарной санитарии. - М. : Колос, 1969. -495 с.

4. Рекомендації щодо санітарно-мікробіологічного дослідження змивів 3 поверхонь тестоб'єктів та об'єктів ветеринарного нагляду і контролю / методичні рекомендації / О.М.Якубчак, В. І. Хоменко, С. В. Мідик [та ін.]. - К., 2005. $18 \mathrm{c}$. 